\title{
Interpreting texts and the matter of context: Examples from the Book of Ruth
}

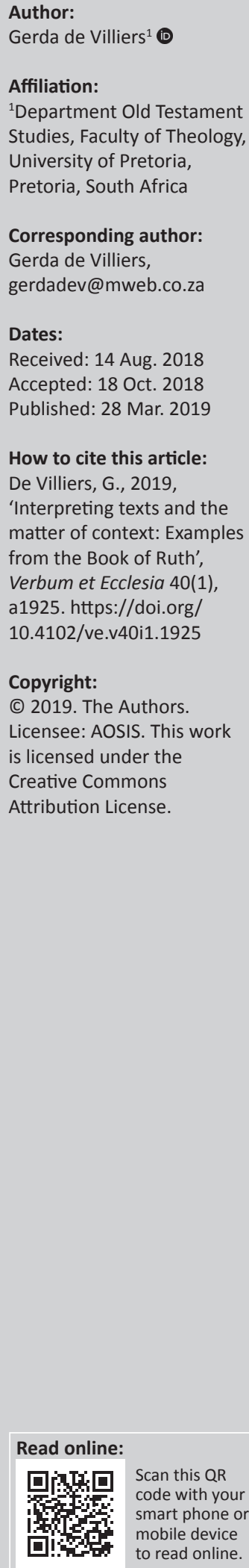

This article aims to explore the matter of context in biblical exegesis and interpretation. Several exegetical approaches are discussed, namely, text-immanent, intertextual comparison, readerresponse criticism, which is subdivided into feminist and postcolonial studies, and historical criticism. The pros and cons of each approach will also be indicated. The Book of Ruth (RB) is subjected under all of these forms of exegesis in order to illustrate how a single text can be interpreted in various, even divergent ways, depending on the approach chosen by the exegete.

Intradisciplinary and/or interdisciplinary implications: This article aims to explore the matter of context in biblical exegesis and interpretation. It examines the biblical Book of Ruth by employing literary and theological theories. Different interpretations are illuminated according to the methodology chosen by the exegete.

Keywords: Exegesis; Hebrew Bible; The Book of Ruth; text; text-immanent; intertext; readerresponse criticism; feminism; Postcolonialism; social identity; context; historic critical.

\section{Introduction}

Interpreting texts and the matter of context: does context matter, or is it completely irrelevant when reading biblical texts? This is a question about exegesis and methodology, and it is the first question the exegete has to ask herself or himself when the aim is to understand the meaning and relevance of a text from the Bible. Several exegetical approaches are possible, and this article will illuminate different interpretations of one text, namely, the Book of Ruth (RB). It begins by discussing a text-immanent approach and is then followed by an intertextual reading of the text. Thereafter, the much popular reader-response criticism and some of its subdivisions receive attention, and the article concludes with some interpretations offered by a more traditionalhistorical critical reading of the text.

\section{Text without context: A synchronic, text-immanent reading of the text}

Since the groundbreaking work of Alter (1981) and later Amit (2001), a literary or narrative approach to biblical texts became popular. Alter (1981:21) and Amit (2001:3) argue that biblical texts, especially narrative and poetic texts, are highly skilled literary works of art; hence, it is possible to analyse and understand such texts in the same way and by the same means as modern-day literature. Thus, by employing the same analytic 'tools' that contemporary literary critics use to analyse and evaluate contemporary literature (structural analysis, narrative analysis, plot, character, etc.), biblical exegetes can also get a grip on the ancient text and its meaning. The focus is thus on the text only and exegesis is carried out by identifying particular literary devices within the text.

The rationale behind such a synchronic or text-immanent approach is that any text is an independent literary work of art, completely capable of standing on its own artistic legs, regardless of its author, its historical context and even its reader (Eagleton 1983:104). Thus, information about the personal life of the author, the circumstances which gave rise to the writing of the text, as well as the intended audience or addressees of the text are completely unnecessary with regard to its interpretation. A literary analysis of a text by means of discerning particular literary devices is sufficient for understanding it, and disclosing its message. Perhaps, biblical scholars find this text-immanent approach to biblical texts attractive, probably because in most cases, especially in the Hebrew Bible (HB), the authors are unknown, and the dating, and subsequently the implied audience are matters of controversy (Prinsloo 1982:4-7). The exegete is really left with the text and only the text; therefore, the methodologies of literary criticism and the analysis of literary devices in a text provide handy instruments and are valuable keys for interpretation. 
With regard to the $\mathrm{RB}$, such a literary immanent reading that focuses mainly on structural and narrative elements in the text was popular, especially during the last two decades of the previous century. Perhaps one may - albeit with caution deduce that such an objective approach to the text is going slightly out of fashion, and so it is necessary to take note of some conclusions drawn by these earlier exegetes.

The best known commentary in South Africa on the RB is probably the one by Prinsloo (1982). Prinsloo analysed all the structural and narrative components of the text, and especially pointed out the artistry of its composition. Others who followed the same exegetical route of an immanent synchronic textual analysis are an article by Grant (1991:425443) and a commentary by Gow (1992). After a careful analysis of the structural, rhetorical and narrative elements in the $\mathrm{RB}$, these scholars reach more or less the same conclusion: although God is hardly mentioned in the RB, he is actively working behind the scenes, he engages ordinary and humble people in his plans and he helps those who help themselves (Gow 1992:109; Grant 1991:441-442; Prinsloo 1982:110). Although these exegetes comment on the fact that the RB may be dated to a particular period in Israel's history, they are of the opinion that the historical context is unnecessary to understand the essence of the meaning of the text. The literary devices in the text itself are sufficient to disclose its message and actualise it for a contemporary audience.

\section{Pros and cons of a synchronic text-immanent approach}

The best that any exegete may learn from a rigid textimmanent approach is that the starting point is always a close reading of the text, that is, to read the text in its original language, whether it is Hebrew, Aramaic, Greek, Syriac, Latin and so on. It is necessary to pay close attention to the choice of words, the syntax and to become aware of the different nuances of words and expressions in the original languages which are often lost in translation. Words are deliberately chosen, and normal syntactical or grammatical constructions are disrupted with good reason. The authors, although they are unknown, wish to convey something in their choices of the language and arrangement of the words that they use.

Yet, as early as 1982, in the heydays of immanent textual readings and structural analysis, Fisch (1982) remarks:

Are we not in danger of exchanging the tangible world of the Bible for a merely abstract construction, a diagram in which the storm and stress of history, its contradictoriness as well as its hope and promise have no place? (p. 426)

In other words, a structural analysis with a pattern of arrows and stripes conveys nothing of the struggles, the memories, promises and disappointments that impelled the writing of the text - and its structure for that matter. A focus on the text, and only the text, brackets it off from the issues and struggles in life.

\section{Intertextuality: A synchronic, comparative reading of texts}

Although Fisch (as per above) correctly observes that a synchronic text-immanent exegesis disregards the 'strum und drang' of those elements that gave rise to the origins and development of a text, he himself resorts to a likewise synchronic approach in his article on the RB. He sets out to compare different biblical texts regarding content, motifs and themes, and identifies what he calls a 'Ruth corpus'. Consequently, he links the Ruth narrative to the overarching narrative of the Abraham family and his nephew Lot - Lot of course being the patriarch of the Moabites (Gen 19:37). Fisch concludes that where the ways of Abraham and Lot separated in Genesis 13, they are once again brought together in the characters of Boaz and Ruth, and thus the 'Ruth corpus' forms part and should also be read in the light of Israel's greater Heilsgeschichte (Fisch 1982:425-442).

Other renowned Old Testament (OT) exegetes who also follow an intertextual approach are Van Wolde (1997:1-28) and Nielsen (1987:13-17), both in 1997, and later Berger (2009:253-272). Regarding Nielsen's commentary on the RB and Van Wolde's article on intertextuality on the narratives of Ruth and Tamar, the following observations can be made. Both Nielsen (1987:13-17) and Van Wolde (1997:8-12) note intertextual parallels between the Ruth narrative and the narrative of Judah and Tamar, yet their interpretations differ. Nielsen (1987:17) reads the story in a positive way and suggests that the Ruth narrative aims to tell a new and better narrative than Genesis 38: in the Ruth narrative, God intervenes by selecting Ruth to become the foremother of King David. Regarding Nielsen's commentary, she proposes a pre-exilic dating for the RB, perhaps shortly after the reign of King David, in order to provide an apology for David's possible Moabite ancestry (Nielsen 1987:28-29). Van Wolde (1997:27) is more critical of the Ruth narrative. Firstly, she emphasises the positive transformative actions of Tamar and Ruth, respectively, in the sense that they 'open the eyes' of Judah, Boaz and Naomi, but then she is rather disappointed that both these foreign women seem to give up their identity instead of holding a confronting mirror before the faces of the inside group.

Berger (2009:253-272) observes an intertextual relationship between the Ruth narrative and 1 Samuel 25:2-42 - the David, Nabal and Abigail encounter. He reads the story of Ruth as a moral counter-narrative against the power-hungry, selfish and devious motifs of David, Nabal and Abigail. Unlike the characters in 1 Samuel 25:2-42, Boaz and Ruth 'act with modesty and integrity' (Berger 2009:269). Unfortunately, King David deviated from the good examples set by his forbearers.

\section{Pros and cons of a synchronic intertextual reading}

A reading of a text in relation to other texts that have similar motifs and plots creates an awareness that no text stands in isolation. It serves as a reminder that texts in the $\mathrm{HB}$ are 
in dialogue, either confirming, correcting, criticising or disagreeing with one another. Texts know about other texts and enter into discussion with them.

The problem with an intertextual reading of texts on a synchronic level is that all texts did not originate at the same time; some texts are simply older than others. The context in which the different texts were written is not taken into account, only the narratives are compared, and inferences are drawn by means of illuminating similarities or dissimilarities in the 'texts-as-they-are'. A synchronic intertextual reading engages texts in dialogue as though no time has elapsed between them or, in the case of Berger, takes the canonical order of the Christian Old Testament for granted.

\section{Reader-response criticism}

Reader-response criticism is yet another form of literary criticism; however, the focus is not on the 'text-as-it-is' but on the reader and his/her reception of and reaction to the text. In the beginning of her Ruth commentary, Moen Saxegaard (2010:9) readily admits that she was greatly influenced by Alter's narrative approach to reading biblical texts, and that she deliberately chose to interpret the text from the point of view of the reader. She puts it as follows (Moen Saxegaard 2010):

The most significant difference between the historical-critical methods and narratological approaches is the change in point of view, from seeking to construct the author or editor's point of view behind the text to focusing on the reader's interpretation in front of it ... When 'entering' a role in the text, I give priority to a close reading of the structure of the narrative in order to follow the hints and remarks in the plot and to discover the nuances and artistic qualities in the narrative. (pp. 10-11)

Although this may seem like the text-immanent approach discussed above, it is important to note that the reader plays an active role by not only reading the text but also by entering subjectively into the very plot of the text. The difference lies in the text-immanent exegete who, on the one hand, would perform a structural or narrative analysis on a text in order to find an objective grip on the material and thereby derive at an objective meaning. The reader-response exegete, on the other hand, is fully aware of his or her own presence which is taken into the text, and that the meaning of the text can only be derived by means of subjective engagement between text and reader. Sometimes, the context of the text is taken into account, but that is less important than becoming part of the text itself, as Saxegaard (as per above) puts it, to enter a role in it.

Among the more classical reader-response commentaries on the RB are those of Loader (1994) and Sakenfeld (1999); however, it appears that especially feminist biblical scholars were attracted to this method of exegesis (e.g. the commentary edited by Brenner 1993, A Feminist Companion to Ruth), and postcolonial interpretations of the text soon followed. Consequently, the focus will be on feminist and postcolonial studies, as a subdivision of reader-response criticism.

\section{Feminism and postcolonialism}

Especially with the rise of feminist biblical scholarship and the later development of postcolonialism, the many and varied readings of the RB became evident. Perdue (2005:147) makes it clear that the premise of feminist biblical hermeneutics is that no claim can be laid to an objective interpretation of a biblical text. Feminist exegetes approach the text from various angles; some of them do take the sociocultural context into account (e.g. Meyers 1993:85-114; van Dijk-Hemmes 1993:134-139) by referring to archaeological evidence and extra-biblical sources for information about women in ancient Israel. Others employ the so-called hermeneutics of suspicion to disclose the patriarchal interests and sexism in the Old Testament, and to expose the white male theology prevalent in the exegesis of these texts through many ages (Perdue 2005:159). Hinting towards postcolonial readings of the text, as these developed from feminist interests, Perdue (2005:166) observes that 'womanist biblical interpretation' is an exegetical approach that originated among black Afro-American feminists whose hermeneutics stem from their socio-cultural background in their struggle against slavery, racism and patriarchy. Womanist biblical scholars argue that oppressive social strategies were often justified by white racist chauvinists who used the Bible in order to oppress and even abuse women.

Postcolonial exegesis protests against the way that European colonists employed the Bible to colonise territories and impose their religion and Western values upon the indigenous peoples. Consequently, postcolonial exegetical strategies attempt to reclaim the Bible by reading it from an indigenous perspective, devoid of any traces of Eurocentrism. With regard to South Africa, the volume, Postcolonial Perspectives in African Biblical Interpretations (see bibliography for details), edited by Dube, Mbuvi and Mbuwayesango (2012), is an excellent example of postcolonial as well as African Feminist/ Womanist interpretations of biblical texts and is worth mentioning.

It would come as no surprise that the RB also attracted and still attracts the attention of a number of Feminist and Womanist scholars: this book is one of two books in the HB that bears the name of a woman, and the protagonists of the narrative are two women. Pui-lan and Yee are two Asian exegetes who live in the USA, and by referring to the RB, they address the issue of foreignness from the perspectives of Asians living in the Western world. In her essay, Pui-lan (2005:100-121) indicates that Asian immigrants are marginalised in the Unites States (US) and that the RB accordingly appeals to powerful hegemonic societies (like the US) to make space for 'others' on their planet.

Yee (2009:119-140) argues along similar lines, and like Puilan she is concerned that foreigners, especially Asians in the US, are not accepted unconditionally in Western societies. They are expected to conform to the culture and customs of the Western world. Therefore, Yee voices her critique against the RB: like Van Wolde (see above), she regrets the fact that 
Ruth has given up her Moabite identity by fully accepting Judahite customs and religion.

Claassens is a South African scholar who spent some time in the US, and like Nielsen and Van Wolde (above) she also sees parallels between the Ruth narrative and Tamar in Genesis 38. Claassens finds the female characters in these stories to be inspiring for women who find themselves in oppressive situations (Claassens 2012:659-674). She uses the term 'dehumanisation' and 'dehumanising situations' to indicate those situations in which human beings are stripped from all dignity. Owing to various circumstances, Naomi, Ruth and Tamar were 'dehumanised' in one way or another. Yet, Ruth and Tamar had the courage to undertake risks by transcending the societal boundaries of their time (Claassens 2012:667), thereby alerting Judah and Boaz to see the face of the 'other' and have mercy. Subsequently, Claassens points out 'dehumanising' situations in the contemporary world like the holocaust and Afro-American slaves on the plantations in South America (Claassens 2012:665-666), and the role that women played to resist those people and powers that stripped them from their human dignity. Narratives like those of Ruth and Tamar set an example of the resistance women can offer in unfair situations dominated by patriarchal structures that prevent them from reaching their full potential (Claassens 2012:673), and furthermore encourage everyone to resist powers that deny the human dignity of others.

Masenya, also from South Africa, calls herself a 'black Womanist scholar' and she has written extensively on the RB from an African perspective. This article cannot deal with all her articles and because space is limited, only a few will be discussed briefly. Masenya is a very good example of an exegete who employs reader-response criticism in the text and brings it to the context - not the socio-historical context of biblical Israel, but she brings the biblical narrative to her personal African context. She states: 'In my view, what hinders present-day Bible readers' appreciation for the content of biblical books is that the books are informed by the ideologies and agendas of the narrators ... (Masenya 2010:2) - and that exegetes were mostly white European males, also with their own ideologies and agendas.

In an article published in 2010, Masenya discusses Ruth as ěšet hayil - the worthy woman as proclaimed by Boaz in Ruth 3:11 (Masenya 2010:253-272). She observes that this may not have been Ruth's idea of herself but an expression of the narrator's ideas and point of view which he put in the mouths of Boaz and the rest of the assembly - all men. Masenya then proceeds to analyse various African proverbs from various African cultures in order to determine an 'ēšet hayil', that is, what do traditional African societies expect from women and the roles that they are supposed to play (Masenya 2010:256261). She concludes: 'The basic determinant of worthy (ideal) womanhood in African culture is a woman's capacity to be a wife (whether in a monogamous or polygamous marriage relationship) and a mother' (Masenya 2010:261), which is of course a patriarchal point of view. According to her, the same goes for Boaz and Ruth and the Israelite society of their time: marriage and having children, especially boys, were important to define a woman's status and identity. Patriarchy lays down the rules for and definitions of womanhood; they are restrictive and leave no room for those women who deliberately decide to remain single, not to have children or prefer to have relationships with women and not men (Masenya 2010:268-270). ${ }^{1}$

Masenya's responses to the RB especially illuminate the ways in which biblical texts can be used / abused to justify patriarchal structures and to oppress and confine women to specific gender roles. Furthermore, her Womanist readerresponse approach to the text serves as a reminder that no exegete is able to distance herself / himself from the text and her / his personal context. Textual exegesis from an objective point of view by means of a supposedly objective methodology seems unattainable.

\section{Pros and cons of reader-response criticism}

Feminist, Womanist and postcolonial studies emphasise that every exegete reads a text through her / his subjective lenses and responds in a subjective personal way to the text. But is it a matter of 'anything goes' and 'everyone reads in the text that she or he wants to'? The limits of reader-response criticism and the strategy of 'reading against the grain' may be stretched rather too far, and in this regard I refer to the unsavoury debate between Fewell, Gunn and Coxton in the years 1988-1989.

The argument is sparked by an article by Fewell and Gunn (1988:99-108) in which they analyse Naomi's silences in the Ruth narrative and come to the conclusion that in reality Naomi is a discontented scour, deeply jealous of her Moabite daughter-in-law and resents her presence. Coxton reacts (1989:26-27) by accusing Fewell and Gunn of misinterpretation and a superficial perspective. Upon which Fewell and Gunn become personal and accuse Coxton: 'Like many men before him, he wants an altruistic Naomi, he wants a self-sacrificing Ruth, he wants a perfectly heroic Boaz' (Fewell \& Gunn 1989:46). They continue to portray Boaz as a man who is overcome by lust the moment he sets his eyes on Ruth. Still, he has to protect his public image, and in order to do that, he plays the game of being a 'pillar of strength' (Fewell \& Gunn 1989:45-59). Then comes his ideal moment to act as beneficiary and redeemer of a hopeless and worthless widow before the eyes of everyone present in the gates of the city. 'He is in the business of effecting a dubious marriage in such a way as make [sic] it public triumph' (Fewell \& Gunn 1989:52).

1.This article provides neither space nor scope to discuss all of Masenya's articles on the Book of Ruth. See, for example, Masenya (2013). In Masenya's article, a woman with the praise-name of Moremadi re-tells the Ruth narrative, but juxtaposes and interweaves it into an African context. Both cultures stress a heterosexual marriage and male offspring. The article concludes with interviews that Masenya conducted with single women in an African context - either by widowhood or by conducted with single women in an African context - either by widowhood or by choice - and their responses to the Ruth narrative; See also Masenya 2016. Here, Masenya investigates the role that deceased males play in African and ancient Israelite cultures. Masenya 2016 concludes that:

We must critically engage with the religio-cultural world embedded in the Book of Ruth (as well as in the African religio-cultural world), a world in which the male dead continue to control the lives of living women, with a view to the welfare of those who might be victimised in the name of culture. (p. 95) 
Exegesis that 'reads against the grain' certainly has its merits; however, in this case, one may agree with Peter Lau's remarks that Fewell and Gunn's personal involvement in the text as readers 'renders some of their interpretations of the characters' motivation unconvincing' (Lau 2011:16).

\section{Social identity}

Lau's study is unique in the sense that he approaches the RB from a social-scientific perspective and his book bears the title: Identity and Ethics in the Book of Ruth: A Social Identity Approach (Lau 2011). His focus is on the ways that the social identity of an individual was construed in the ancient world, and then he employs these different categories of identity and self-understanding on the protagonists in the RB: Naomi, Ruth and Boaz. Lau argues that all three protagonists' original identity underwent some form of transformation, which resulted in making an ethical appeal on the implied reader of the time. ${ }^{2}$ Although identity was mainly based on descent in the ancient world, and set rules for behaviour and conduct existed, both Ruth and Boaz had the courage to overstep social boundaries by acting in an 'ethical' manner. At the end of his commentary, Lau concludes: 'The acceptance of Ruth into Israelite society challenged the notion that entrance was based solely on descent, rather decision and personal character are also important' (Lau 2011:192).

\section{Pros and cons of social studies}

Since the last decade of the previous century, New Testament scholars in particular have read the New Testament from a socio-cultural perspective. They emphasised that the world view of the 1st century CE (Common Era) was vastly different from the modern one of the 20th (and one may add the 21st) century, and attempted to construe the unique world view of ancient societies. Honour and shame, prescriptive societal roles for men and women, and especially the dyadic orientation of ancient societies - that is, an individual sees herself or himself always through the eyes of the group that she or he belongs to - were determinative with regard to human identity (e.g. the volume of Malina 1993 where these topics are addressed, and which Lau also employs in his analysis of the plot and characters in the RB).

Yet, it is necessary to ask the question whether contemporary methodologies of cultural anthropology, sociology and social psychology can be appropriated directly to the ancient world. Texts in the HB and the New Testament do seem to indicate that ancient societies operated in the ways that are proposed by social-scientific theories. However, the ancient world is a lost and inaccessible world, and the texts only hint at what it may have been like. The ancient world should be approached with caution, especially when making use of modern theories and methodologies.

2.In this regard, it is important to note that Lau dates the RB to the Second Temple Period. Like the exegetes who are discussed in the next section of the article, he considers that the dating of a text plays an important role in understanding it.

\section{Text, intertext and context of the text}

Except for Lau (see above), most exegetical approaches thus far discussed in the article do not regard the dating of the text to be important for its understanding. The focus is rather on the text as is, the narrative itself and the personal context of the present reader in her or his personal capacity. However, a number of exegetes do take the context of the text seriously, that is, the context of the first addressees of the text. These exegetes argue that a text is a product of particular historical circumstances in which it attempts to answer particular questions within a community who often grapple to make sense of seemingly senseless events. Furthermore, many texts are also in dialogue with other texts, either earlier or contemporary documents that have become problematic or do not address burning issues in the community. In other words, texts have a history of origin and development. In the beginning of his Ruth Commentary, Frevel (1992) remarks:

\footnotetext{
... das Erste (Alte) Testament [ist] zu großen Teilen langsam gewachene Fortschreibungsliteratur, an der oft viele verschiedene Autoren gearbeitet haben. Überarbeitet wurden die Texte meist dann, wen sich die äußeren Umstände für die Rezeption der Literatur in der Gemeinschaft geändert hatten, sei es, da $\beta$ eine neue politische Situation entstanden war ... (p. 25)
}

In other words, a text may have originated in particular historical circumstances, but as these situations chance, texts are 'over-written' or new texts are produced in order to respond to changing conditions. Furthermore, the final 'textas-it-is' is mostly not the production of one single author; several authors may have laboured through many decades before establishing the biblical version that is read today.

With regard to the RB, the works of Georg Braulik played a major role that influenced subsequent exegetes to read the text in a way that takes the text, its dialogue with other texts and its context into account (Braulik 1996:61-138, 1999:1-20). Most exegetes nowadays agree with Braulik and date the context of the RB, that is, the 'time of narration', to the late postexilic period (see discussion below), although the 'narrated time' is set against the backdrop of the 'time of the judges'. Braulik $(1996: 115,117)$ coined the term Gegengeschichte - counter-history - in order to indicate that the RB is especially in dialogue with the 'community law' of Deuteronomy 23:47, which prohibits Moabites and Ammonites from entering the community of Yahweh - the Lord. Instead, the RB tells a Gegengeschichte - a story that counters this prohibition, a story where a Moabitess is successfully and without any protest integrated into the Judahite community and even becomes the foremother of King David.

Braulik's observations are supported by many other scholars as well; for example, Fischer 2001:62; Korpel 2001:233; LaCocque 2004:25; Matthews 2004:212; Grätz 2007:277; Köhlmoos 2010:xv, 4; Cohn Eskenazi and FrymerKensky 2011:xli, 4-5; Lau 2011:45; Cook 2015:17. In the words of Korpel (2001:233), the entire RB is 'a programmatic 
pamphlet in the guise of a captivating idylle'. Also, Matthews (2004:212) agrees that the RB 'stands as a broad argument against the policy of "ethnic purity" found in Deut $12-26$, and especially the prohibition against Moabites in Deut 23:4'.

The reference to Deut 23:4-7 invokes another partner in the textual dialogue, namely, Nehemiah 13:1-3, which initially seems to quote Deuteronomy 23:3-4 but turns out to be a radical interpretation of the passage (Nihan 2011:77). Nehemiah's concern is the 'mixed marriages' in the Second Temple period; however, he does not stop by prohibiting marriages of Israelites with Moabites or Ammonites only but insists that all 'mixed marriages' be dissolved (Neh 13:23-25; likewise Ezra 10 records the sending away of foreign wives). Cohn Eskenazi and Frymer-Kensky (2011:xxxviii-xlii) observe that the marriage between Boaz and Ruth was actually a 'mixed marriage' and these two scholars remark that one can observe a 'lively internal community debate' within biblical sources (Cohn Eskenazi \& Frymer-Kensky 2011:xli). This becomes obvious, especially with regard to the intertextual disagreement between the RB, and passages like Deuteronomy 23:4-5, Nehemiah 13:1-3, 23-25 and Ezra 10. ${ }^{3}$

When the RB is read as being in debate with those passages in Deuteronomy, Ezra and Nehemiah above, another perspective on the book becomes evident. Many scholars pointed out that there were different views concerning Israelite identity during the Second Temple period, and they discern two circles of influence. The most powerful of these were the exclusivists, who regarded that the real and 'true Israel' should consist of only the descendants of those who went into exile (e.g. Japhet 2006:97; Kessler 2006:103; Lau 2011:162-163; Römer 2007:167-169; Southwood 2011:205-206 esp. 205). Yet, there was another circle who envisioned an inclusive Israel, and voices of these inclusivists resonate in texts like Jonah, Isaiah 56:1-8 and the RB (Grätz 2007:280281; Scharper 2011:31-32). ${ }^{4}$

Thus, the context of the RB appears to be the Second Temple period, and it becomes evident that the text of the RB addresses an important issue within the postexilic community: that of Israelite identity. Should YHWHworshipping foreigners be included in Israel or not? The text also enters into intertextual debate, especially with those texts that argue for an exclusive Israel, by telling a story of a foreigner who, although forbidden by the 'law', deliberately chose $\mathrm{YHWH}$ as her God and from beginning to end demonstrated her solidarity with YHWH's people. Accordingly, Israelite identity should not be determined by descent only but mainly in terms of religion: that is, the 'true Israel' should consist of all who worship the God of Israel, YHWH.

3.The question of 'mixed marriages' during the Second Temple Period has been addressed thoroughly in the volume edited by Frevel 2011. See also De Villiers and Le Roux (2016:3-4).

4.See also the discussion of De Villiers and Le Roux (2016:2-3).

\section{Pros and cons of a text, context and intertext analysis}

A historical critical analysis of a text sets parameters for its interpretation: not 'anything goes' according to the whims and woes of the reader. The RB's intertextual debate with texts like Deuteronomy 23:4-5, Nehemiah 13:1-3 and Ezra 10 furthermore illustrates that there is not 'one clear message' for every question in the HB. All texts are open for reinterpretation within a new context in which new questions arise. This is especially important with regard to contemporary issues, for example, like homosexuality, homosexual and other relationships, which seem to be forbidden by certain texts in both the Old and New Testaments. The RB would make out a strong case for accepting lesbian, gay, bisexual, transgender, queer, intersexual, a sexual (LGBTQIA) orientations and relationships in Christian churches, as long as they agree to worship God, show their solidarity with the community and abide by the principles of Christian relationships of mutual commitment, trust, respect and support, until death do they part.

But this is exactly the problem: the basis of inclusivity in the $\mathrm{HB}$ is religion. It does not address an issue like xenophobia. What about the influx of Muslims into Christian countries?

Furthermore, in the $\mathrm{HB}$, no text can be dated for certain. A (re)construction of the context remains an exegetical endeavour, and the exegete is led by what she or he is able to discern from hints in the text. Yet, there is uncertainty in dating of texts and reconstruction of context, and it remains a guessing game, albeit an informed guess.

\section{Conclusion}

This article explored several exegetical strategies of reading texts in the HB. The RB served as an example to emphasise the role of the exegete, her/his exegetical approach and her/ his interpretation of the book. Many and varied ways in which one text can be interpreted were illuminated, which affirmed that the exegetical approach of the exegete plays a key role in the interpretation of a text. The pros and cons of every one of these were discussed. Ultimately, one is not better than the other; each has its own merits and drawbacks.

\section{Acknowledgements Competing interests}

The author declares that she has no financial or personal relationships that may have inappropriately influenced her in writing this article.

\section{References}

Alter, R., 1981, The art of Biblical narrative, Basic Books, New York.

Amit, Y., 2001, Reading Biblical narratives. Literary criticism and the Hebrew Bible, Fortress Press, Minneapolis, MN

Berger, Y., 2009, 'Ruth and inner-Biblical allusion: The case of 1 Samuel 25', Journal of Biblical Literature 128(2), 253-272. https://doi.org/10.2307/25610182

Braulik, G., 1996, 'Das Deuteronomium und die Bücher ljob, Sprichwörter, Rut', in E. Zenger (ed.), Die Tora als Kanon für Juden und Christen, pp. 61-138, Freiburg, Herder. 
Braulik, G., 1999, 'The Book of Ruth as intra-Biblical critique on the deuteronomic Law', Acta Theologica 1, 1-20.

Brenner, A., 1993, (ed.), A feminist companion to Ruth, Sheffield Academic Press, Sheffield.

Claassens, L.J.M., 2012, 'Resisting dehumanization. Ruth, Tamar and the quest for human dignity', The Catholic Biblical Quarterly 74, 659-674.

Cohn Eskenazi, T. \& Frymer-Kenski, T., 2011, Ruth, The Jewish Publication Society, Philadelphia, PA.

Cook, L.S., 2015, Reading Deuteronomy. A literary and theological commentary, Smyth \& Helwys Publishing, Inc., Macon, GA.

Coxon, P.W., 1989, 'Is Naomi a scold? On responding to the Book of Ruth', Journal for the Study of the Old Testament 45, 25-37. https://doi.org/10.1177/ 030908928901404503

De Villiers, G. \& Le Roux, J., 2016, 'The Book of Ruth in the time of the Judges and Ruth, the Moabitess', Verbum et Ecclesia 37(1), a1587. https://doi.org/10.4102/ ve.v37i1.1587

De Villiers G.G., 2016, 'Israel se Identiteit en die Boek Rut', Unpublished Ph.D. dissertation, University of Pretoria.

Doob Sakenfeld, K., 1999, Ruth. Interpretation: A Bible commentary for teaching \& preaching, John Knox Press, Louisville, KY.

Dube, M.W., Mbuvi, A.M. \& Mbuwayesang, D., (eds.), 2012, Postcolonial perspectives in African Biblical interpretations, No. 13, Society of Biblical Literature, Atlanta, GA.

Eagleton, T., 1983, Literary theory. An introduction, Basil Blackwell Publisher Limited, London.

Fewell, D.N. \& Gunn D.M., 1988, 'A son is born to Naomi! Literary allusions and interpretation in the Book of Ruth', Journal for the Study of the Old Testament 40 , 99-108. https://doi.org/10.1177/030908928801304006

Fewell, D.N. \& Gunn, D.M., 1989 'Boaz, pillar of society: Measures or worth in the Book of Ruth', Journal for the Study of the Old Testament 45, 45-59. https://doi. org/10.1177/030908928901404505

Fisch, H., 1982, 'Ruth and the structure of covenant history', in Vetus Testamentum 32, pp. 425-442, E.J. Brill, Leiden.

Fischer, I., 2001, Rut, Herder, Freiburg im Bresgau.

Frevel, C., 1992, Das Buch Rut, Verlag Katholisches Bibelwerk GmbH, Stuttgart.

Frevel, C. (ed.), 2011, Mixed marriages. Intermarriage and group identity in the second temple period, T\&T Clark, London.

Gow, M.D., 1992, The Book of Ruth. Its structure, theme and purpose, Apollos, Leicester.

Grant, R., 1991, 'Literary structure in the Book of Ruth', Bibliotheca Sacra 148, pp. $425-443$.

Grätz, S., 2007, 'Second temple and the legal status of the Torah: The Hermeneutics of the Torah in the Books of Ruth and Ezra', in G.N. Knoppers \& B.M. Levinson (eds.) The Pentateuch as Torah. New models for understanding its promulgation and acceptance, pp. 273-287, Eisenbrauns, Winona Lake, IN.

Japhet, S., 2006, From the rivers of Babylon to the highlands of Judah. Collected studies on the restoration period, Eisenbrauns, Winona Lake, IN.

Kessler, J., 2006 'Persia's loyal Yahwists: Power identity and ethnicity in Achaemenid Yehud', in O. Lipschits \& M. Oeming (eds.), Judah and the Judeans in the Persian Period, pp. 91-121, Eisenbrauns, Winona Lake, IN.
Köhlmoos, M., 2010, Ruth, Vandenhoeck \& Ruprecht, Göttingen

Korpel, M.C.A., 2001, The structure of the Book of Ruth, Koninklijke Van Gorcum, Assen, Netherlands.

LaCocque, A., 2004, Ruth, transl. K.C. Hanson, Fortress Press, Minneapolis, MN.

Lau, P.H.W., 2011, Identity and ethics in the Book of Ruth. A social identity approach, De Gruyter, Berlin.

Loader, J.A., 1994, Ruth. Een praktische bijbelverklaring, Uitgeverij Kok, Kampen.

Malina, B.J., 1993, The New Testament world. Revised edition. Insights from cultural anthropology, Westminster John Knox Press, Louisville, KY.

Masenya (ngwan'a Mphalele), M., 2010, 'Is Ruth the 'êšet hayil for real? An exploration of womanhood from African proverbs to the threshing floor (Ruth 3:1-3)', Studia Historiae Ecclesiasticae 36, 253-272.

Masenya (ngwan'a Mphalele), M., 2013, 'Engaging with the Book of Ruth as single African women: One African woman's reflection', Verbum et Ecclesia 34(1), article \# 771, 9 pages, https://doi.org/10.4102/ve.v34i771

Masenya (ngwan'a Mphalele), M., 2016, 'Who calls the shots in Naomi's life? Reading the Naomi-Ruth story within the African religio-cultural contexts', Acta Theologica 24, 84-96, https://doi.org/10.4314/actat.v36i1.6S

Matthews, V., 2004, Judges and Ruth, Cambridge University Press, Cambridge.

Meyers, C., 1993, 'Ruth: A product of women's culture?', in A. Brenner (ed.), A feminist companion to Ruth, pp. 85-114, Sheffield Academic Press, Sheffield.

Moen Saxegaard, K., 2010, Character complexity in the Book of Ruth, Mohr Siebeck, Tübingen.

Nielsen, K., 1987, Ruth. A commentary, transl. E. Broadbridge, Westminster John Knox Press, Louisville, KY.

Nihan, C., 2011, 'Ethnicity and identity in Isaiah 56-66', in O. Lipschits, G.N. Knoppers \& M. Oeming (eds.), Judah and the Judeans in the Achaemenid period: Negotiating identity in an international context, pp. 67-104, Eisenbrauns, Winona Lake.

Perdue, L.G., 2005, Reconstructing Old Testament theology: After the collapse of history, Fortress Press, Minneapolis, MN.

Prinsloo, W.S., 1982, Die Boek Rut, NG Kerk-Uitgewers, Kaapstad.

Pui-lan, K., 2005, Postcolonial imagination and feminist theology, SCM Press, London. Römer, T., 2007, The so-called Deuteronomistic history, T\&T Clark, London.

Scharper, J., 2011, 'Torah and identity in the Persian period', in O. Lipschits, G.N. Knoppers \& M. Oeming (eds.), Judah and the Judeans in the Achaemenid period: Negotiating identity in an international context, pp. 27-38, Eisenbrauns, Winon Lake, IN.

Southwood, K.E., 2011, 'The Holy seed: The significance of endogamous boundaries and their transgression in Ezra 9-10', in O. Lipschits, G.N. Knoppers \& M. Oeming (eds.), Judah and the Judeans in the Achaemenid period: Negotiating identity in an international context, pp. 189-224, Eisenbrauns, Winona Lake, IN.

Van Dijk-Hemmes, F., 1993, 'Ruth: A product of women's culture?' in A. Brenner (ed.), A feminist companion to Ruth, pp. 134-139, Sheffield Academic Press, Sheffield.

Van Wolde, E., 1997, 'Texts in dialogue with texts: Intertextuality in the Ruth and Tamar narratives', Biblical Interpretations 5(1), 1-28. https://doi.org/10.1163/ $156851597 \times 00012$

Yee, G.A., 2009 "“She stood in tears amid the Alien Corn:" Ruth, the perpetual foreigner and model minority', in R.C. Bailey, T.B. Liew \& F.F. Segovia (eds.), They were all together in one place? Toward minority Biblical criticism, pp. 119-140, Society of Biblical Literature, Atlanta, GA. 